\title{
THE BRITISH WORKING CLASS AND THE GENERAL ELECTION OF I 868
}

(continued from previous issue)

\begin{abstract}
IV
In the middle of September Howell wrote to James Stansfeld: "I understand that Mr. Glyn is much pleased with our reports: Mr. Stanhope has also spoken highly of them. We shall be glad if Mr. Glyn and yourself will write to Mr. Morley on this subject if you feel satisfied with our preliminary work". ${ }^{1}$

Most of the first $£_{1,000}$ in the "Special Fund" had been spent. Howell was eager to go on; to enlarge the number of his agents in the field and to use his contacts with national trade union secretaries to gain access to local lodges. ${ }^{2}$ As he told Stansfeld, "we are preparing for the next part of our contract - work". ${ }^{3}$ But "work" required a steady flow of cash. The agents were paid ro/- per day for their time; a further Io/- per day for their expenses; and on top of this they were given their railway fares. ${ }^{4}$ Morley, who had paid $£ 6_{3} / / /^{5}$ towards

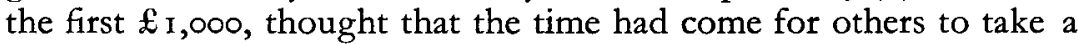
greater share of the burden. He drafted an appeal which was submitted to Stanhope. It was intended to be "strictly private" and to be sent only to "safe" friends, "about 25 or 30 in number". It was not to be printed or lithographed. ${ }^{6}$ Despite these precautions, Stansfeld did not favour this proposal. ${ }^{7}$ It was not consistent with the whole transaction being as secret as possible. Morley would just have to make the best of it and Howell would have to keep him happy with a stream of flattering notes.

Throughout September and October, Howell kept reminding Morley that "the entire Liberal Party will owe you a debt of gratitude for the great aid you have rendered them in this election". 8 At the

${ }^{1}$ Howell to James Stansfeld, M.P., I 8 th. Sept. 1868.

2 Howell to D. Guile, 23 td. Sept. 1868 and on 24th. Sept. letters to Allan, Applegarth,

Coulson and the secretary of the cordwainers.

${ }^{3}$ Howell to J. Stansfeld, M.P., 22nd. Sept. I 868.

4 E.C.R.L. Minutes of "Special Meeting", Ioth. August 1868.

5 Howell to James Stansfeld, 6th. January 1869.

${ }^{6}$ Howell to J. Stansfeld, 26th. Sept. 1868.

7 Howell's letters to S. Morley \& J. Stansfeld, 2nd. Oct. 1868.

8 Howell to S. Morley, 3oth. Sept. 1868.
\end{abstract}


same time he stressed the amount of useful work that still might be done. Stansfeld "told Cremer and myself when we came together to see you that we must go on and some arrangement would have to be made with you.

I have applications today for men to go to Sheffield, Whitehaven, Cockermouth, Droitwich, Worcester and many other places. We have men out now involving a large outlay and I feel therefore rather anxious. We told Mr. Stansfeld that it would require $£ 2,000$ and I think it will, but it will not exceed that. I will write to a few men to send you cash towards the amount". ${ }^{1}$

This was written four days after Morley had sent Howell a cheque for $£_{200^{2}}$ and only a week elapsed until Howell was begging for more. "We have gone on increasing expenses up to date and have already exceeded the amount received by nearly $£ 200$. This morning I have received a letter from $H$. Scudmore Stanhope... wanting us to deal with no less than I4 Boroughs".3 This brought $£_{300}$ from Morley and a hefty contribution came in from the Kells at Bradford. ${ }^{4}$ Nevertheless right up until the end of the election Howell got a stream of requests for money. "I am requested to write to you for a further advance. We now think, as the election will take place earlier than some of us thought, that about another five hundred pounds will complete the entire scheme. Mr. Stansfeld, at our last meeting, considered the repayment to you quite safe.

It was at first thought that $£_{5,000}$ would be required, but the entire amount up to now will be but $£ 1,400 " .{ }^{5}$ Morley paid up once more. His cheque for $£ 500$ made up the total, already mentioned, of $£_{1,900}$ on account of the "Special Fund".

Armed with these fresh supplies, Howell increased his staff of workers who were hurrying from one part of the country to another establishing committees, addressing meetings, giving advice to the local unions and generally employing themselves as the Liberal Candidates in the boroughs thought best. Howard Evans, Blackburn, Hinton, Young, Mead and Nicolson joined the original fifteen agents. ${ }^{6}$ The accounts of the special fund show that veterans such as Lloyd Jones, Ernest Jones and Holyoake, "the thin-voiced, intrusive, consequential Holyoake" as Marx called him, ${ }^{7}$ also received small amounts for expenses.

\footnotetext{
1 Howell to S. Morley, 26th. Oct. 1868.

2 Howell to Morley 22 nd. Oct. 1868.

${ }^{3}$ Howell to S. Morley, 3 ist. Oct. 1868.

4 Howell to Kell and Co Bradford, 4th. Nov, 1868.

${ }^{5}$ Howell to S. Morley, 9th. Nov. 1868.

${ }^{B}$ Cash Ledger, Special Fund Folios x 27-1 33 Ref. 4058.

7 Marx to Engels, 27th. July I 866.
} 
If these men were not fully employed in boroughs to which they were directed as a result of instructions from Glyn or Stanhope, Howell would write to a liberal candidate and offer his assistance. This sometimes gave rise to misunderstandings. William Rathbone at Liverpool, for example, suspected that there must be political conditions attached to offers of working-class support. In a revealing letter Howell sought to reassure him. "You are quite mistaken as to the import of my letter. You are not supposed to endorse anything, only tell me how to serve you... in no case would you be mixed up with our movement either in Liverpool or here". ${ }^{1}$

While Lloyd Jones, who would only work for candidates who were sound on the Labour Question, went to Blackburn; ${ }^{2}$ while such men as Hales and Mottershead were helping Dronfield and the Sheffield workers to defeat Roebuck ${ }^{3}$ (there cannot have been a politically conscious worker in the country who would not have preferred Mundella, for all his brass-voiced cunning, to Roebuck); Howell and Cremer were devoting more and more of their own time to dealing with Glyn's "special” constituencies. Wherever there was a really "delicate" situation they were on hand to deal with it directly.

When Samuelson, whose son Howell had helped to place in Cheltenham, started arousing dissatisfaction among radicals and trade unionists in his own constituency of Banbury, the Reform League's Secretary did his best to silence the critics. "Mr. Samuelson is not quite up to our mark", he confessed, "but he is considered as a sound liberal, even more so than the one you name. He is sound on Education, and advanced on the subject of capital and labour and generally votes right in the House. He has aided us in the agitation for reform, although not going in for our programme. If we advised any contest the Liberal Party would say that we were dividing the liberal interest and", he added, "we should lose friends"."

Howell got Robert Applegarth, Secretary of the Amalgamated Society of Carpenters and Joiners, to go down to Banbury and try and ease matters. But he had to explain to Samuelson that he had the reputation of being opposed to trades unions. ${ }^{5}$ Although he sent $£$, the Honourable Member for Banbury resented being censured. Howell thanked him for the money and tried to smooth the path with

${ }^{1}$ Howell to W. Rathbone, M.P., $27^{\text {th. Oct. } 1868 .}$

2 Lloyd Jones to Howell, 26th. Oct. 1868 and Howell to Mottershead, 27th. Oct. 1868.

${ }^{3}$ Howell to A. J. Mundella, 26th. Oct. I 868 and to Hales and Brighty on 2nd., 7 th. Oct. and on roth. Nov. 1868.

4Howell to J. Butcher Esq. of Banbury, 22nd. Sept. 1868. (Headed "private”.)

${ }^{5}$ Howell to B. Samuelson, M.P., Ist. Oct. 1868. 
a remark which was characteristically at once "Liberal" and olympian: "Trades Unionists, like Employers, are not over wise, they want everything their own way. But some of us must step between them and folly and try and test all questions by reason and common sense". ${ }^{1}$

The possibilities of a serious split in Banbury were probably not very great. Howell devoted his best efforts to more serious cases. He told Stanhope, "We are trying all in our power to close up the Liberal ranks in several places and I think we shall have some success". Five days earlier Glyn had cancelled a visit to Gladstone explaining "I had a private intimation late last night, that I must see Beales today upon some matters of very pressing and immediate importance which admit of no delay $\&$ which I dare not depute to my Secretary. I have done it \& though it has cost me my little holiday I feel that good will come of it. Nothing can be more striking than the moderation of these men \& their loyalty in your cause but direct communication with them is a very delicate matter -2 or 3 places will I hope be put right now and I have the comfort of feeling that I have not lost my pleasant visit to you for nothing." To this he added a note: "Please let no one know of my visit to Beales." 3

Despite the heavy air of mystery surrounding all Glyn's references to his work with the League, it is not difficult to conjecture where the "two or three places" were, or the methods which were employed to - in Howell's phrase - "close up the Liberal ranks". From other letters in the Gladstone and Howell collections it seems likely that the three constituencies involved at this stage were Kidderminster, Brighton and Stoke.

Reference has already been made to the position in Kidderminster. Howell might tell provincial officers of the League: "Your men are our men. We shall never be disloyal to our branches"; ${ }^{4}$ but within a week he was able to tell Morley that he had helped to dispose of "the excellent Bristowe", the choice of the Kidderminster Reform League. ${ }^{5}$

Brighton was one of Glyn's "special" constituencies. It was a doublemember one and Henry Fawcett sat as the junior representative. Despite his devotion to many of the teachings of the Manchester School, Fawcett had some qualities that might well commend him to working-class electors. Professor Beesly had gone out of his way to recommend him when he first came forward for Brighton in $1864 .^{6}$

1 Howell to B. Samuelson, M.P., 7th. Oct. I 868.

2 Howell to H. S. Stanhope, M.P., 29th. Oct. I 868.

${ }^{3}$ Glyn to Gladstone, 24th. Oct. I 868. BM Add. Mss. 44347 f. 212.

4 Howell to R. White of York, 24th. Sept. 1868.

${ }^{5}$ See first part of this article in Vol. V (r 960), Part 3, pp. $45^{2-453 .}$

6 E. S. Beesly, The Brighton Elections, in: Bee-Hive, 13 th. Feb. 1864. 
Odger declared that no man had done more than he had to help amend the Master and Servant Acts. ${ }^{1}$ John Stuart Mill pointed out that he was a friend of co-operation, an advocate of the claims of the agricultural labourer, and was in favour of compulsory education and the payment of election expenses out of the rates. ${ }^{2}$

The complication at Brighton arose from the fact that William Conningham, who had once been one of the two representatives, decided to come forward as a candidate. Unlike Fawcett, Conningham had been closely identified with the Reform League and was one of its Vice Presidents. Howell tried, without success, to find him a seat elsewhere. There was a real danger that the working class vote would be split, for Fawcett was already running in harness with the senior member, James White. Because he was well known in the town and in the League, Conningham had considerable working-class support. He even managed, and it was a brilliant stroke, to get Col. Dickson to turn up at one of his opponent's meetings and declare it a duty to "support those who supported the Reform League." Dickson said he was for Fawcett and Conningham. "Mr. White looked so comfortable that he was sure that he could take care of himself." ${ }^{3}$ Meanwhile, a Tory who saw an opportunity of profiting from these divisions had arrived on the scene.

Doubtless Howell himself preferred Fawcett to Conningham and would not follow Dickson in regarding the choice before the Brighton electors in any other light. The Whips always were likely to favour the incumbents except in such unusual circumstances as those at Sheffield. Consequently, Howell wrote to the Secretary of the Brighton branch of the Reform League in favour of Fawcett: "The working men of England cannot afford to lose the services of one of their best and most uncompromising champions..." 4 The branch subsequently organised a large meeting in favour of Fawcett at which Odger was the principal speaker. ${ }^{5}$ Odger was one of the favourite targets of the more vulgar middle-class newspapers. "He has not derived any benefit from the repeal of the duty on soap", said the Brecon County Times (3 ist. October 1868). The Pall Mall Gazette commented that "his father was a miner and his mother was mad". It is interesting to note that Fawcett went out of his way to pay a tribute to Odger and to protest that "a bitter personal attack may possibly frustrate all hope

\footnotetext{
${ }^{1}$ Brighton Guardian, I8th. Nov. 1868.

2 Ibid., I Ith. Nov. I 868.

3 Brighton Guardian, I Ith. Nov. 1868.

4 Howell to J. Thompson, 28th. Oct. 1868.

5 Brighton Guardian, 18 th. Nov. 1868.
} 
of obtaining that united action that all true Liberals ought to desire." 1 Conningham finished at the bottom of the poll and resigned from the Reform League. ${ }^{2}$

Like Brighton, Stoke was on Glyn's list of "special” constituencies, and it probably figured in his conversation with Beales. If the affair at Brighton caused unpleasantness, the arrival of Robert Hartwell at Stoke in mid-October was much more serious politically. Hartwell said that he "came there to ask them to support an interest which he regarded as being superior to either Liberal, Conservative or any party interest; he came to ask them to support the interests of Labour". ${ }^{3}$ His programme included distinctively working-class demands, and he placed a considerable emphasis upon them. He could present himself, as Conningham could not, as an authentic working-class leader. There was no Tory in the field, and one of the adopted Liberals, Rodin, was an ironmaster who had been reproached with trying to crush unionism. Thus, Stoke raised issues of principle which were absent in Brighton. Glyn told Gladstone: "I am doing all I can to get Hartwell away from Stoke".4 However, an account of his efforts and of the attitude of Howell towards Hartwell's candidature is best reserved for discussion in the last part of this article.

Wherever a trade unionist, or a reformer, or someone with a recognisable claim to the confidence of working-class electors came forward, he found he had to enter the lists against the Whig cliques; that these cliques had frequently come to an arrangement with the middle-class radicals to divide the representation of the Borough between them and that he was faced with the choice of withdrawing or "dividing the Liberal interest". There was never any money forthcoming from the Reform League to support such men. There was not even any encouragement, but rather the reverse. There were public letters from Beales and private letters from Howell which had the effect of disowning and under-mining them. There were private visits to constituencies by Howell and Cremer which gave rise to rumours of intrigue and charges of betrayal.

When Alexander Macdonald, the miners' leader, came out as a candidate for Kilmarnock, he was supported by Professor Beesly. Beesly observed that the sitting member, the Whig, Bouverie, belonged to a class "who only want to keep things as they are workmen, if they know their own interests, want to make almost

${ }^{1}$ Brighton Guardian, 30 th.Oct. 1868, reprinting a letter from the Daily News.

${ }^{2}$ Howell to W. Conningham, 2 ist. Nov. 1868.

3 The Staffordshire Sentinel, I 7 th. Oct. I 868.

${ }^{4}$ Glyn to Gladstone, 3rd. Nov. I 868. BM. Add. Mss. 44347 f. 226. 
everything different from what it is..." He told Macdonald, "You are one of the few representatives of unionism I know who would be able to fight the battle with effect in such an Assembly as the House of Commons". He concluded with the remark, "Those who begin do a great thing and deserve to be remembered". ${ }^{1}$

Howell took no interest in the Scottish elections - except in Kilmarnock. A few days before Macdonald's candidature was announced he wrote to a correspondent there informing him that Edwin Chadwick intended to stand for that constituency. "If he does, do aid him all you can; at any rate do not give your pledges too early for any one else". ${ }^{2}$ One can only conjecture as to whether Howell knew at the time of writing that the foremost leader of the British miners was about to enter the field. At any rate, Macdonald found himself embarrassed by discussions about the attitude of the Reform League towards the election ${ }^{3}$ and this - combined with a shortage of money - forced his retirement. Chadwick had declared himself delighted with the very advanced programme of the workmen of Edinburgh and Leith, and Macdonald, in retiring, spoke in his favour. ${ }^{4}$ However, the electors apparently preferred the persecutor of Ernest Jones to the author of the new poor law. He was soundly defeated.

In Nottingham, there were, at one time, four Liberal candidates in the field for the two seats. One of them was J. J. Merriman, a barrister, a member of the International and a prominent figure in the Reform League. A. J. Mundella had helped to establish an elaborate Liberal Electoral Association in this Borough, ostensibly with the object "that the working men should have the honest choice of one representative, and the moderate party another, and he hoped that the two would work together... it must not be said that a large constituency like that was in the hands of a clique Number 30 or anything else..." 5

Merriman, anticipating the criticisms of Ostrogorski, argued that this machine gave the appearance of popular participation while leaving power in the hands of an oligarchy. He was not surprised when another "Working Man's Candidate" appeared on the scene in the shape of P. W. Clayton. Clayton does not appear to have been any more of a working man than Merriman himself and his views on the mutual responsibilities of labour and capital were fairly described in

1 E. S. Beesly to A. Macdonald, 7th. Sept. I868. Kilmarnock Standard I2th. Sept. 1868.

2 Howell to McEwen, 24th. August 1868.

${ }^{3}$ Kilmarnock Advertiser, 3 rst. Oct. 1868.

4 Ibid., I4th. Nov. 1868.

5 Speech by A. J. Mundella, Nottingham Review, 4th. Sept. I 868. 
the local press as such as "the wealthiest millionaire might have listened to with complacency". 1

Merriman made it plain that he was not going to abide by the decision of a "primary", in which ward committees whose officers were nominated from on top were accorded an important role. ${ }^{2}$ But he found the Reform League unsympathetic. In September he participated in a stormy meeting of the General Council and "complained of the conduct of the 'two persons' who had visited Nottingham. He thought himself badly treated. The Secretary replied to the attacks on himself and $\mathrm{Mr}$ Cremer, and assured the Council that the statements upon which the complaints were founded were inaccurate in every particular. The Council generally accepted the explanations given". ${ }^{3}$ When Clayton was officially adopted, the Executive expressed its satisfaction at the manner in which the Liberal Party in Nottingham had chosen its nominees and urged that they be supported "to the exclusion of all personal considerations". It added, "the surest and quickest mode of ensuring the triumph of our principles is to be found in the most complete organisation of the Party". ${ }^{4}$ Merriman retired from the fight with a general denunciation of everyone connected with the proceedings, including Samuel Morley, ${ }^{5}$ who had refused to arbitrate.

A still more dramatic problem was presented by Halifax. In this borough the electorate had been raised, as a result of the Reform Act, from 1,900 to 9,442 . The workmen wanted to choose at least one of the representatives for themselves and they sent a deputation to the Whigcontrolled Liberal Registration Association to negotiate about this. The Whigs refused to even discuss the matter and they hurriedly formed an alliance between their man, Edward Akroyd, and the other member, who was none other than James Stansfeld.

The local branch of the Reform League adopted the well-known co-operator E.O. Greening as their candidate and despite the fact that Greening was not prepated to make a financial contribution to his own expenses, they swore that they would return him. ${ }^{6}$ The working class was exceedingly well organised in Halifax and the threat had to be taken seriously. Ernest Jones and John Stuart Mill both publicly

1 Nottingham Review, 25th. Sept. 1868.

2 Nottingham Review, 6th. Nov. 1868.

3 G. C. R. L. Minutes, 4 th. Sept. I 868.

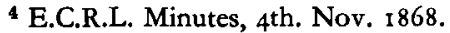

5 Nottingham Review, 6th. Nov. 1868.

6 T. Crimes, Edward Owen Greening, Manchester I923; E. O. Greening to T. Hughes, 4th. Sept. 1868, in: Halifax Guardian, 24th. Oct. I 868. 
supported Greening. However, Stansfeld refused to accept the suggestion that he should break with the Whig. ${ }^{1}$ Akroyd was a large employer and his committee had met the whole expense of registration. ${ }^{2}$

Howell did not shy away from this embarrassing situation. He told Stansfeld that Stanhope had spoken of "the complication at Halifax. Shall we run down to see you or will you be in London this week?" 3 A few days later he wrote, "We shall be very glad to see you and consult as to Halifax". 4 A day or so later he was expressing the hope that "things are all right at Halifax". ${ }^{5}$ Beales intervened by making it plain that the Reform League at national level was not going to follow the local branch. He acknowledged Greening's respectability, his integrity, his sound principles, but he declined to do anything which might run a risk of getting Stansfeld defeated. ${ }^{6}$ Tom Hughes, who served with Stansfeld and P. A. Taylor as an arbitrator in Chelsea where he found against Odger, refused an invitation from Greening to arbitrate in Halifax.

As the campaign went on, Greening found that the wind was going out of his sails. Stansfeld used great skill in focusing more attention on his disagreement with Greening on the Permissive Bill than on their common agreement against Akroyd on the ballot. Greening's personal honour was the object of determined Whig attacks and he referred with some justification to the way in which they "dipped their hands in the gutter and hurled a social Finlen at him". ${ }^{7} \mathrm{He}$ managed to win on the show of hands, but was well beaten at the poll. He himself summed up the lessons of the election: "In this democratic borough they had found that local influence, wealth and position, and the respect men paid to good employers could hold their own against the political enthusiasm and manifest class interest of working men... Those influences to which he had referred were as able now to hold their own and were as omnipotent as in times gone by". ${ }^{8}$ To which he might have added that if the Secretary of the Reform League hated Whigs, he loved middle-class radicals more. "I am", said Howell to

${ }^{1}$ Halifax Guardian, 7th. Nov. 1868.

${ }^{2}$ E. Akroyd to T. Hughes, 9th. Sept. I868, in: Halifax Guardian, 24th. Oct. I 868.

${ }^{3}$ Howell to Stansfeld, I 5 th. Sept. I 868.

4 Ibid., 18 th. Sept. 1868.

5 Ibid., 22nd. Sept. 1868.

${ }^{6}$ Halifax Guardian, 3rd. Oct. I 868.

${ }^{7}$ Halifax Guardian, 3 Ist. Oct. 1868 . - The reference is to James Finlen being hounded out of public life by Parliament and the press for his defence of the Fenians. Finlen was accused of driving his wife mad and leaving his children to starve.

8 Ibid., I 2 th. Dec. I 868. 
Stansfeld, "truly glad to find you in office and in a position to be, close to Mr Gladstone". 1

Hackney was another problem borough. It was here that Col. Dickson a long-standing and active member of the League, came forward as one of the five liberal candidates who contested for the two seats against a single Tory. Dickson had been a most loyal supporter of both Beales and the Secretary. Howell recalled the "military pride" with which the Colonel used to say, "We must support those in authority" ". ${ }^{2}$

In October 1868, Dickson's supporters in Hackney tried to get a grant of money from the Reform League to aid his candidature. This was turned down on the grounds that there was no cash available. ${ }^{3}$ The Hackney leaders, if not Dickson himself, were most indignant about this and since there was obviously a lot of money available for other purposes they threatened to "publish the proceedings". "I don't know what you mean", replied Howell, "come to the Council and all information can be given". 4 Regret was officially expressed when Dickson ended up at the bottom of the poll, but it is quite certain that if his friends had come to the Council all information would not have been given.

A few months after the election was over Howell wrote a letter addressed to one of the other Liberal candidates who had stood at Hackney asking him for money. He stated "We had nothing whatever to do with the Hackney election - we tried hard to keep one of our men away, but he would stand in spite of us. I think it is good to tell you this now that it is all over or perhaps you might think that some of us played a double game". 5

Dickson was a genial person, but not all those who had held high office in the League behaved with his decorum when they found that they were denied support or intrigued against. Charles Bradlaugh, who offered himself as a candidate for the double member constituency of Northampton, had already acquired a great reputation for truculence and aggression. Like Greening in Halifax, Bradlaugh was unable to persuade the sitting Liberal, Gilpin, to break his alliance with the Whig, Lord Henley. Glyn told Gladstone that "Bradlaugh will do harm, but Henley (if either) is in danger. B. is not amenable to the League or I think I'd manage him". ${ }^{6}$

1 Howell to Stansfeld, i ith. Dec. I 868.

2 Howell's Draft Autobiography.

${ }^{3}$ Minutes E.C.R.L., I4th. Oct. I 868.

4 Howell to C. Royal, I6th. Oct. I 868.

${ }^{5}$ Howell to C. S. Butler, sth. April I 869 .

- Glyn to Gladstone, Ioth. Sept. 1868. BM. Add. Mss. 44347 f. 157. 
Howell had to be exceedingly careful. In July he explained to a correspondent in Northampton that he had "never had any official communication to make to $\mathrm{Mr}$ Bradlaugh whatever. He came to this office on June 24th. when our Election Committee was sitting and stated that he was a candidate and meant to fight it out to the last. $\mathrm{He}$ then wished for our aid. The Committee gave no pledge at all, but $\mathrm{Mr}$ Odger was appointed at the next meeting to visit you and ascertain whether he was accepted by you and then to report to us". " Bradlaugh had already announced that his candidature had the "sanction and knowledge" of the Reform League ${ }^{2}$ and the Northampton branch was being congratulated on its choice by branches in other parts of the country. ${ }^{3}$

Howell was in touch with Gilpin. He promised to draw the attention of his colleagues to one of Gilpin's letters and went on to remind the Honourable Member for Northampton that "you were kind enough to partially promise me some little towards our new Club". ${ }^{4}$ The League defined its attitude towards Northampton in two resolutions: one expressed the earnest hope that Gilpin would be returned; the other commended Bradlaugh's plan to submit to the choice of the Liberal electorate as expressed in some kind of primary. ${ }^{5}$ However, the Whigs would have nothing to do with Bradlaugh's proposal. It might have been expected that the League would there and then endorse their own man, but instead Howell and Cremer arranged to get together with the Northampton Branch Committee "to talk over matters quietly and confidentially.". ${ }^{6}$ Howell wrote to the local President, "I trust the tenor of the resolutions will not cause any breach with our Northampton Branch".?

In fact, the local branch split and Bradlaugh plainly thought that Cremer, who warned against the electoral consequences of adopting an atheist, made matters worse. ${ }^{8}$ The seceders joined forces with the teetotallers to support a rival candidate, Dr F. R. Lees, an eccentric Hegelian. Bradlaugh declared, very plausibly, that had Dr Lees been a paid agent of Lord Henley he could hardly have acted differently. ${ }^{9}$

${ }^{1}$ Howell to S. Clarke, IIth. July I868. (Clarke was corresponding Secretary of the Northampton Branch. He was charged with withholding correspondence favourable to Bradlaugh. National Reformer, 23 rd. August 1868 .)

2 National Reformer, 5 th. July I 868.

${ }^{3}$ Ibid., I 2 th. July 1868.

4 Howell to C. Gilpin, M.P., 29th. July I 868.

${ }^{5}$ Minutes of G.C.R.L., 22nd. July 1868 \& Howell to the editor of the Daily Telegraph, 6th. August I 868.

- Howell to Yorke, Sec, of Northampton Branch, I4th. August I 868

7 Howell to F. Wells, ioth. August 1858 .

${ }^{8}$ National Reformer, 23rd. August r 868.

9 National Reformer, 22nd. Nov. 1868. 
He was extremely suspicious about the exact part played by Howell and Cremer and he kept the General Council and then the Executive occupied with his grumbling and searching questions. ${ }^{1}$ But he did not dare to complain too loudly in public, for open hostility with the League leaders might have been more damaging to his cause than was their ambiguous neutrality. Howell was able to boast to both Goschen and Glyn: "Bradlaugh has felt aggrieved with us. He thought that we could give him money for his election, but we kept to our arrangement and would not swerve even for one of our own Council". 2

By this time Odger was also feeling "aggrieved". A brilliant orator and probably the most popular working-class leader of the day, he was optimistic and easy-going to a fault. Unlike Howell he had no taste for administration and was most unreliable. He was always promising to go to Northampton or Stafford or somewhere else and then failing to turn up. During his visit to the West Country in August he got separated from Coffey and could not be found for several days. Unlike most of his contemporaries in the Labour leadership, Odger could unbend. He enjoyed visiting pubs where, standing upon a table, he would give a recitation from Shakespeare. Both before and after the election, Howell found cause to complain of Odger whom he accused of talking bosh; $;$ behaving badly ${ }^{4}$ and speaking "in very bad taste"; ${ }^{5}$ being dilatory; $;^{6}$ getting in the sulks $;^{7}$ and even of getting "nearly drunk" and suggesting "to settle some difference with a fight. His conduct was disgusting".8

The shoemaker seems to have assumed that as a result of his services in August he would be found a seat, if not in Stafford then in Chelsea, where the "Chelsea Association of Reasoners" were looking for a working-class candidate. ${ }^{9}$ In the London constituency he confidently agreed to the issue between himself and Whig, Sir Henry Hoare, being decided by a panel of three advanced liberals, P. A. Taylor, Tom Hughes and James Stansfeld. It was a great shock to him and to his supporters when the verdict went against him. ${ }^{10}$ Howell described Odger's reaction to Glyn: "Mr Stansfeld, Mr Hughes, and Mr Taylor are supposed to be tools for getting rid of the Working Man's Candidate

1 Minutes G.C.R.L., 4th. and 16th. Sept. 1868. Also Minutes of ECRL I 3 th. Jan. $1869^{\circ}$

2 Howell to Glyn, 30th. Nov. I 868.

${ }^{8}$ Howell's diary, I6th. Jan. I 868.

4 Ibid.

5 Ibid., 17th. Jan. 1868.

Ibid., 25 th. March 1868.

7 6th. Jan. 1869.

8 Ibid., 3 rd. August 1869.

- National Reformer, 23rd. August 1869.

${ }^{10}$ Chelsea News, 3 ist. Oct. \& 7 th. Nov. 1868. 
for that miserable Tory, Sir H. Hoare". ${ }^{1}$ However, on the eve of the election Glyn was becoming frightened. He told Gladstone: "The ultra party, so loyal throughout are beginning to give me anxiety..."." From the beginning Glyn had been astonished by the moderation of the Reform League leaders and their unconditional loyalty to Gladstone and he was not surprised that they were showing some signs of restiveness. He admitted to his Chief that he would have liked to have seen one or two workmen in the House. Howell and Cremer were the obvious choice, but they had never said that they wanted to be candidates until the last moment when they came forward for the hopeless constituencies of Aylesbury and Warwick. ${ }^{3}$ Howell's agents had reported that Warwick needed "an advanced Liberal of good position".4 Howell had asked, "What do you think of the Hon. Lyulph Stanley, son of Lord Stanley of Alderley? He is a fine Liberal, good speaker, and of good family". ${ }^{5}$ Cremer hardly fulfilled this last condition and he was unable to make any headway against a Whig-Tory compact.

There was a similar compact in Aylesbury where Howell tried to induce the Whig, Rothschild, to enter into an alliance with him. Glyn observed: "Howell has no chance at Aylesbury, but I am very much disappointed at the line Rothschild has taken. He has refused today to combine or act \& in strong terms - I have done all I can Howell is a true man $\&$ has been of great use to me. He has unfortunately chosen the wrong place \& went to A. against my advice - a stranger cannot win there \& Rothschild's treatment has done harm \& will create bad feeling. The upper part of our party are so jealous \& [... ] just now - I have written to Howell, Morley, Goschen, Forster, \& others have all written to me in his favour - The League are very angry, but they have waited too long". ${ }^{6}$

Rothschild explained that his principal supporters would have left him if he had made an alliance with Howell. These people had added that "in consequence of the warm contest in the Borough an ill-feeling had sprung up between the labourers and their employers". ${ }^{7}$ Apparently the mere appearance of a working man, even one whose election address contained no reference to the Trades Union Bill and

\footnotetext{
${ }^{1}$ Howell to Glyn, 3rd. Dec. I 868 (Headed "Private").

2 Glyn to Gladstone, x 2th. Nov. I 868, BM Add. Mss. 44347 f. 24 I.

${ }^{3}$ Glyn to Gladstone, I3th. Nov. I 868. BM. Add. Mss. 44347 f. 107 (catalogued as if written in March).

4 ER: Warwick: Hales and Brighty.

5 Howell to R.S. Gold of Warwick, 4 th. Sept. 1868.

6 Glyn to Gladstone, 13th. Nov, I868. BM Add. Mss. 44347 f. 107.

7 N. M. de Rothschild to Howell, 23 rd. Nov., 1868.
} 
who favoured every effort to "economise on national expenditure", 1 was the signal for a furious class struggle. In fact the root of the matter would appear to have been simple Whig resentment that any kind of working man should presume to enter the best club in Europe. There was nothing left for Howell to do but recall his own adage; "well, caste is not confined to any class, it rankles in all of us". ${ }^{2}$

\section{V}

"Everywhere the proletariat is the tag, rag and bobtail of the official parties, and if any party has gained strength from the new voters, it is the Tories". ${ }^{3}$ It was in these terms that Engels summed up his first impressions of the results of the election of 1868 . The Conservative press consoled itself with the same thought: in the factory districts, in the large boroughs, Disraeli had more support than Gladstone. J. S. Mill had referred to Gladstone as "the one English Minister of past or present times who has best deserved, and obtained in largest measure, the confidence of the working classes". But the Tory "Standard" pointed out that Gladstone owed his good fortune to "sectarian ascendancy" and to a "despotic priest-hood", not to the workmen. The Conservatives were victorious in Lancashire and the big Towns; Gladstone in "bigotry-ridden" small boroughs." This was a gross over-simplification, but it had an undeniable element of truth in it.

"Not a single working-class candidate had a ghost of a chance, but my Lord Tomnoddy or any parvenu snob could have the workers' votes with pleasure". 5 This was a matter about which virtually the entire press, whether Liberal or Tory, expressed its thankfulness and relief. "The notorious BEALES,- the blasphemous BRADLAUGH,Hartwell, ERnest Jones, and every man of the same kind has been rejected, unless we are to place Mr. CARTER of Leeds in the same category, and that we cannot properly do, as he came out not as a nominee of one class, but of the party as a whole... The working men of our land are not wishful for separate representation or for class legislation". This dispelled the last fears of "abuse of the electoral power". ${ }^{6}$ "Next to the triumph of the Liberal Party, the most original feature in the elections is the utter collapse and downfall of the League

1 G. Howell: Address to the Electors of the Borough and Hundreds of Aylesbury, 22nd.

Oct. I 868 .

${ }^{2}$ Howell's Diary, 2oth. Jan. 1868.

3 Engels to Marx, 18th. Nov. 1868.

4 Standard, I 8 th. Dec. I 868.

${ }^{5}$ Engels to Marx, I8th. Nov. 1868.

- Huddersfield Observer, 2 Ist. Nov. 1868. 
and its adherents: No single member of the Hyde Park connection, from Mr Beales down to Mr Howell, has obtained a seat". ${ }^{1}$

A week or so before the election the Reform League and its leaders were being mocked and taunted in the Tory press. "BEALES and ODGER and Bradlaugh gather the sweets, and Hoare, and Dilke and VerNON HARCOURT consume them. We trust that working men are satisfied with this division of labour. They may be tempted to grumble, possibly, at a dispensation which gives them all the work and their aristocratic friends of the Whig connection all the wages, but they should be careful, lest by their murmurs they 'divide the Liberal Party"."2

The satirical journal, Judy, printed a cartoon entitled "No Third Class". Various middle-class Liberals were shown on board "the underground railway to Westminster". A notice announced; "Workmen's train will not run". Tom Hughes appeared as a porter informing a crowd of carpenters, builders and shoemakers:

"No Third Class can travel! Why must I repeat? Some Lord or some swell has bespoke every seat. So 'step it' my hearties! Pack off with your tools Directors have power to alter their rules."3

Within the League Howell tried to put the best face he could on matters. Beales' defeat was explained by the absence of the Ballot; Col. Dickson was too late in the field; Odger's withdrawal was "a matter to be deeply regretted by us all". The defeat of Cremer and himself was chiefly due to the action taken by the Whigs. He suggested that they could derive some satisfaction from the return of a number of friends: Samuel Morley for Bristol; Sir Wilfrid Lawson for Carlisle; Samuel Plimsoll for Derby; Dr Brewer for Colchester; Mr James Howard for Bedford; and MrR. M. Carter for Leeds. All these men were Vice Presidents, but Howell could not carry his colleagues with him when he went on to suggest that they could also congratulate themselves on having Mundella, Illingworth; Holmes and Reid (the members for Hackney!); Dilke and Hoare (the members for Chelsea!) and MacArthur for Lambeth in the new Parliament. This was drastically amended in the final report, and one new passage was added stating that "the League will not feel restrained, at its discretion, presenting and supporting candidates at future Elections, merely because there may happen previously to be other candidates in the field, provided there

1 Northampton Mercury, 2 Ist. Nov. 1868.

2 Standard, 2nd. Nov. 1868.

3 Judy, inth. Nov. 1868 . 
appears to be in any such case, a fair portion of the constituency in favour of the League candidate."1

In public Howell expressed his disappointment and associated himself, albeit reluctantly, with the resolve to pursue a more independent policy in future; in private, he spoke proudly of what had been achieved. He described to Samuel Morley the difficulties with which Cremer and himself were confronted and made an estimate of the contribution which had been made to the Liberal victory. "Mr Bradlaugh thought that we should have given him pecuniary and other help. This we absolutely refused, because the money was given to us for a special object viz. to try and win a number of seats from the Tories. We had a list given to us containing the names of 92 Boroughs returning no less than rog conservative members all of which were open to attack. Not one shilling of the money was given to us to empower any man to fight against Liberals, unless indeed we include Mr. Roebuck under this term". (The fact that this express condition was attached to the "Special Fund" nowhere appears in the League Minute books. However, members of the Executive knew that negotiations about cash were being carried on with Gladstone's whips; they were certainly ingenuous if they imagined that all Mr Morley's cheques would be blank ones.)

Howell's letter to Morley continued: "Now I felt, as the man having more control over the fund than anyone else, as the Executive Officer, that I should not be doing my duty if I allowed the money so subscribed to be used in Northampton against Lord Healey. In addition to this Col. Dickson thought that we could find him money for the contest in Hackney and deputations were sent asking for large sums. This $\mathrm{Mr}$ Cremer and myself refused. Even Mr Odger seemed aggrieved that we did not turn our attention to Chelsea. We felt obliged to refuse except sending a speaker to aid now and again when they had returned to town for a day or two. This has placed us rather in antagonism. But as to the expenditure of the funds, our finance committee went over the whole of the accounts up to the Saturday before the Council meeting and everything was examined and certified as correct. So that there was no complaint as to the keeping of the accounts, or indeed spending of the money, but they wanted the names for the public papers of those who had been the means of raising this fund. You are aware, Sir, that Mr Stansfeld and Mr Glyn strongly object to their being known in connection with the matter. I think yours had better not appear either except you allow it to be used simply as the Treasurer for

' Howell's draft of the Report and Balance Sheet of the Reform League, May Ist.-Nov. 3oth. I868. (In letter book for I 868. Folios 829-833. The Report was adopted in the E.C. R.L. Minutes after the entries for 25 th. July $\mathrm{I} 868$.) 
the Fund. That the money has been honestly and fairly used I pledge my honour and will allow any fair inspection of the accounts, but I will never dishonour myself by giving names except first being authorised to do so.

Mr Cremer and myself will call tomorrow (Wednesday) at one o'clock to consult you on this subject". (Throughout all the discussions which took place on the Special Fund, Howell attempted to treat criticisms of his political honour as if they were criticisms of his personal honour in money matters.)

"As for the work done - this will tell its own tale.

We sent out deputations of two each to 85 Boroughs covering the whole of England and Wales. We employed 27 men, good speakers and adapted for electioneering work. These men were employed from August ist up to the end of the Election, a period of seventeen weeks.

We held about 240 public meetings, sent out circulars and other printed matter, and embodied our first labours in the reports which you have read and which Mr Glyn so much praised and valued. This money has paid time, travelling and all other expenses, except that I find a printer's bill in London for about $£$ I 6 , so that the work done with the money spent, is not a matter to be ashamed of.

I think that we helped to dislodge about thirty conservatives from old strongholds and where they beat us was where our friends were over-sanguine of success and consequently not earnest enough in their work.

These will tell pretty well the work done without all the minute details. We will give more when we call if you require it."1

In the nature of the case it is exceedingly difficult to verify Howell's claim respecting the number of seats won. He told Glyn: "We secured 49 of the seats which we attacked as you will find on investigation."2 A month later he sent Stansfeld a list of the 85 Boroughs, the amount spent in each, and indicated "those constituencies where we consider that we did some service towards securing the success of the Liberal candidate." 3

There were forty-seven such constituencies. ${ }^{4}$ This estimate can be

1 Howell to S. Morley, ist. Dec. I 868 (Headed "Private").

2 Howell to Glyn, I 2 th. Dec. I 868.

${ }^{3}$ Howell to Stansfeld, 6th. Jan. 1869 .

"Of the 47 seats listed as "won" the following were mentioned in the "Election Reports": Bath; Buckingham; Cambridge (2 seats); Cheltenham; Derby; Durham; Exeter; Grantham (2 seats); Guildford; Helston; Ipswich; Kidderminster; Knaresborough; Leeds; Liverpool; Maldon; Marlborough; Newport; Sunderland; Tewkesbury; Tiverton; Warrington; Whitby; Wigan; Christchurch; Cockermouth; Colchester; Cricklade; Mon- 
made to coincide with the one given to Glyn because Howell explained in an accompanying letter that he could have added Bristol, "where we prepared the way before hand", and Brighton, where "we prevented Mr. Conningham doing serious mischief". In the eight Boroughs returning fourteen members which Glyn had classed as "special", the results were definitely disappointing. Mundella was returned at Sheffield, and Brighton and Stoke were secured, but elsewhere the Tories were victorious; although in Rye and Northallerton it was by the narrowest of margins.

In fact, the figure of 49 represents the total number of Liberal gains from the rog Tory seats which were attacked, while the earlier reference to 30 gains is apparently an estimate of the number of cases in which Howell, Cremer and their agents worked to decisive effect either by agitation and organisation among workmen as in Sheffield; by helping to secure the withdrawal of a candidate, as at Kidderminster; or by depriving the "rogue elephant" of support, as at Brighton. There is no evidence that this estimate was questioned by Morley, Glyn or Stansfeld, all of whom showed by word and deed that they were highly satisfied with the services rendered. Thirty seats might seem neither here nor there in a majority of I I 2, but had the League pursued an independent policy of applying pressure from without, an embarrassingly high price might have had to be paid for a much smaller majority.

Two matters require special emphasis. The immense value to Glyn of getting a great deal of information and routine electoral work done cheaply; work which had to be done even if it is impossible to make any exact measure of its importance in terms of seats gained. The expenditure of the "Special Fund" was made up as follows: ${ }^{1}$

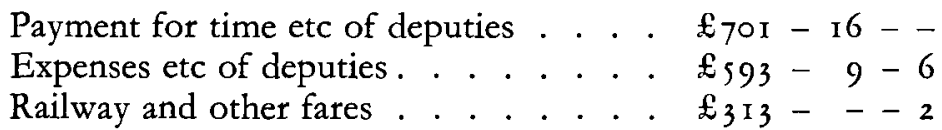

mouth, and Newark. (30 places, 32 seats.) The reader will note Guildford is included - it was won by 20 votes. The inclusion of Liverpool suggests that Howell's claims to have helped ought not to be taken too seriously. The city returned 3 members, and before Joseph Chamberlain showed the way in Birmingham, the minority party could count on securing one seat.

The other Is seats listed as won were: Burnley; Bodmin; Canterbury; Carlisle; Devonport; Dover; Gravesend; Kendal; Salisbury; Wenlock; Windsor; Bedford; Montgomery; Sheffield and Stoke. ("Secured" was written against the last named.)

Canterbury had been represented by Butler-Johnstone. Sympathetic to the claims of Labour, he was a Tory. In Grantham, Kendal, Marlborough, Tiverton [sic], Wenlock and Montgomery, there were no contests.

1 Repott of the Finance Committee (Mottershead, Weston, Worley), 9th. December I 868. 


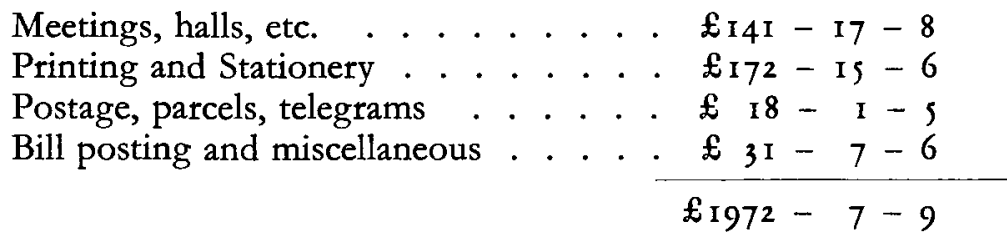

It will be seen that this represents an outlay of about $£_{17}-$ Io - per seat attacked and - if the figure of 49 is taken as the number of seats gained - then the cost of each gain was only $£ 40$. The money was, in fact, expended fairly evenly over the boroughs visited; Blackburn, in which $f_{103}-2-8$ was expended, was easily the most expensive of the 85 boroughs. ${ }^{1}$

The second feature of the way in which the agreement worked, which must have given Glyn special satisfaction, was the manner in which secrecy about it was preserved. "We believe", said Howell and Cremer, "that you are satisfied that we preserved our connection with you as secret as possible considering the peculiar organisation and body of men with which we had to deal"."2

No doubt secrecy was important to Glyn for a variety of reasons. The Whigs could not be expected to share his confidence in the men of the "Hyde Park connection" and would have suspected, no matter how unjustly, that he was everywhere using the League, as he was in Sheffield to support the Liberal and Radical wing of the party against them. They might have construed the whole agreement as a conspiracy to undermine local autonomy and establish a powerful central office staffed with the most unsavory representatives of the mob. And how could Glyn reassure them without discrediting Howell and Cremer among working-class electors? It was hardly likely that the workingclass leaders whom he used would have enjoyed the same influence if it was generally known that they were all being paid three or four times the skilled workers wage out of subsidies supplied by Samuel Morley, and that their labours were being directed by Stanhope, Stansfeld, and himself.

In the event very little appeared in the press at the time, beyond a paragraph or two in the Standard which referred to "the mysterious funds" of the Reform League. ${ }^{3}$ This could easily be ignored or dismissed as an insinuation calculated to aid the Tory Party. It was not until some years later that charges began to be made in public and there was talk of the corruption and destruction of the League by

1 "Copy of Expenditure on Account of the 'Special Fund' at the late general Election, I 7 th November I 868", accompanying Howell's letter to Stansfeld, 6th. Jan. I 869.

2 Howell and Cremer to an unnamed correspondent, I 3 th. Feb. 1869 (headed "Private").

${ }^{3}$ Standard, I6th. Dec. 1868. 
political mercenaries working in the interests of "that ghastliness, that knavery called liberalism". ${ }^{1}$ In $187 \mathrm{I}$, Beesly explained the passage of the Criminal Law Amendment Act by the fact that workmen had been sold at the election of 1868 . He said that some trade union officers had got money or "money's worth" by working for wealthy politicians instead of for their members. ${ }^{2}$ Howell was not mentioned by name, but he unwisely rushed forward to repudiate these "dastardly" and "unmanly" attacks."

This was followed by Marx' more general reference at the Hague Congress to "almost all" the recognised English Labour Leaders being sold to "Gladstone, Morley and Dilke". It was not until I874 when a German paper, Der Volksstaat, published an unsigned article by Engels that some precise and detailed disclosures were made.

Engels used the elections of 1874 as an excuse for a review of the condition of working-class politics in England. He pointed to the absence of an independent workers' Party and argued that this was "understandable in a country in which the working class has shared more than anywhere else in the advantages of the immense expansion of its large-scale industry. Nor could it have been otherwise in an England that ruled the world market; and certainly not in a country where the ruling classes have set themselves the task of carrying out, parallel with other concessions, one point of the Chartists' programme, the People's Charter, after another". However, he saw the Reform Act of 1867 as a "turning point". "Whereas under the old franchise the workers had been to a certain extent compelled to figure as the tail of the radical bourgeoisie, it was inexcusable to make them go on playing that part after the Reform Bill had opened the door of Parliament to at least sixty working-class candidates". Nevertheless this is what they did. "In order to get into Parliament the 'labour leaders' had recourse, in the first place, to the votes and money of the bourgeoisie and only in the second place to the votes of the workers themselves. But by doing so they ceased to be workers' candidates and turned themselves into bourgeois candidates. ${ }^{4}$ They did not appeal to a working-class party that still had to be formed but to the bourgeois

1 The Republican, Ist. Sept. and Ist. Oct. $187^{\circ}$.

2 E. S. Beesly, The Division on the Trades Union Bill, in: Bee-Hive, 29th. July 1871.

${ }^{3}$ G. Howell, Professor Beesly and the Pall Mall Gazette, in: Bee-Hive, 4th. Nov. 1871 .

4 This point had been made at the time by Beesly: "it is said that all candidates who offered themselves expressly as representatives of workmen were rejected. I ask, in what sense did they represent workmen? What did they offer to Labour? Why, the very workmen who stood laid but faint stress on the industrial question... Perhaps they feared to alienate middle-class supporters and expected the workmen to divine their benevolent intentions. This was a fatal mistake". Bee-Hive, 12th. Dec. 1868. 
'great Liberal Party'... The radical bourgeoisie has sense enough to realise that the election of workers to Parliament is becoming more and more inevitable; it is therefore in their interest to keep the prospective working-class candidates under their control and thus postpone their actual election as long as possible. For that purpose they have their Mr Samuel Morley, a London millionaire, who does not mind spending a couple of thousand pounds [sic] in order, on the one hand to be able to act as the commanding general of this sham labour general staff and, on the other, with its assistance to let himself be hailed by the masses as a friend of labour, out of gratitude for his duping the workers".

Engels then referred to "the Potters, Howells, Odgers, Haleses, Mottersheads, Cremers, Eccariuses and the rest of them - a conclave of people everyone of whom had served, or at least had offered to serve, during the previous Parliamentary elections ( 1868 ), in the pay of the bourgeoisie, as an agitator for the 'great Liberal Party"'.1

There is no evidence that anybody in England paid the least attention to this article nor is there any reason to believe that Glyn, who by this time had succeeded to his father's title as Lord Wolverton, would have lost a moment's sleep over it. Engels' charges were not supported, nor have they been up until now, by detailed documentary material.

What really requires some explanation is how it was that the workingclass press, and more particularly the Bee-Hive, never made any disclosures about the "Special Fund". Up until i 868 there had been the most deadly emnity between George Potter, the manager of that paper, and the Junta with which Howell and Cremer were associated. Howell and Cremer claimed credit, and quite rightly, for the skill with which they silenced noisy and troublesome critics within the League, but on the face of it, it was a still greater achievement to have persuaded Potter to forego the pleasure of exposing the intrigues of the "filthy pack". Here, surely, was a theme ready made for Hartwell. One can imagine him assuming his nom de plume of SCOURGE and laying about the conspirators who, hiding behind a veil of secrecy, made a deal with Gladstone; sacrificed their own colleagues and lined their own pockets. Nothing of this sort appeared, but there is no evidence that Potter was employed or rewarded with any of the money in the "Special Fund".

The solution to this problem appears to be that the ubiquitous Samuel Morley, along with the usual collection of wealthy employers

1 F. Engels, The English Elections, in: Der Volksstaat, 4th. March 1874. (Reprinted in English in: Karl Marx and Frederick Engels on Britain, Moscow 1953, London 1954; pp. $464-470)$. 
and liberal politicians, had made a quite separate arrangement with Potter. During the election of 1868 , Potter supported the candidature of Daniel Pratt at Lymington. J. M. Hare, in introducing Potter to a meeting, said: "Ask Samuel Morley and other great men, his character, and they will tell you they depend in a great measure on George Potter for keeping the working men of England right". ${ }^{1}$

This dependence of Morley upon Potter, and still more of Potter upon Morley, is confirmed by the discovery of a circular, headed "Confidential": "The General Election and Working Men". It reads in part, "Several influential members of Parliament and other Gentlemen, friends of the working classes, seeing that the general election is close at hand, when the newly enfranchised working men will be called on to exercise their rights as citizens in the election of representatives to serve in the new Parliament; and believing that the the importance of the support of the working classes to the Liberal Party cannot be over-estimated, have readily subscribed towards a fund for the purpose of helping the conductors of the Bee-Hive to extend the circulation of that paper among the industrial classes.

They intend also to publish a series of special articles upon political subjects of the deepest interest, and circulate them widely among working-class voters, to guide them at this important crisis in sustaining the LIBERAL PARTY..." The circular gave the names of I 7 persons who had already subscribed $£_{440}$. Morley and Daniel Pratt had supplied £ roo each; while A. S. Ayrton, C. S. Butler, and Sir Henry Hoare, - opponents of Beales, Dickson and Odger respectively - were numbered among the other subscribers. ${ }^{2}$

This document would appear to provide a sufficient explanation of the silence of the Bee-Hive on the Glyn-Howell agreement. Further, it helps to explain the rapprochement between Potter and the Junta. It was difficult to continue a quarrel in which both parties were receiving blessings from the same source. Together with some letters in the Henry Solly collection ${ }^{3}$ it helps to substantiate Marx' charge that the Bee-Hive "is really the organ of the renegades, sold to Sam Morley and $\mathrm{Co}^{*}{ }^{4}$

If Howell and Cremer could take no credit for keeping Potter quiet,

${ }^{1}$ S. Coltham, George Potter and the Bee-Hive Newspaper. D. Phil. Thesis, Oxford I956, p. 200.

${ }^{2}$ Dr Coltham discovered this circular in the cover of one of the duplicate volumes of the Bee-Hive kept in the John Burns Collection.

${ }^{3}$ S. Morley to H. Solly, 17 th. Oct. \& 2nd. Dec. 1870 \& 3 rd. January 1871 . (Solly Collection, British Library of Political and Economic Science.)

4 Marx to Beesly, I 2th. June I871. 
they were entitled to congratulate themselves on how they handled some of their colleagues on the Executive Committee of the Reform League. Gladstone had declared after the election that his mission was to pacify Ireland; Howell had a similar task within the Reform League and, for a time, it looked as if it was going to be just as exacting. He told Glyn, "I have never had so much badgering over anything in my life as over this piece of work. Still I feel that we did our work fairly honestly, and well". (There is no sign of a comma after "fairly"!)

George Odger began the attack by insisting that "The E.C. instruct the Secretary to respectfully write to Mr Glyn to know the grounds upon which $\mathrm{Mr}$ Samuda was supported in his candidature by the Liberal Party at the expense of dividing the Liberal interest and after a truer liberal - Mr Beales - was in the field...".2

Odger followed this up by demanding a committee of enquiry into the Tower Hamlets election and also "into the particulars of the visit of Messrs Howell and Cremer to Northampton in reference to $\mathrm{Mr}$ Bradlaugh's candidature and to enquire into and report upon the manner in which the Electoral Committee, or Committees, have conducted their affairs". ${ }^{3}$

This was carried. But in the middle of December a resolution moved by Holyoake and seconded by Davis, "That the report of the Financial Committee do pass" was defeated by one vote. ${ }^{4}$

Howell and Cremer were by now wishing that the League was dead and buried, but it was not so easily despatched. Howell declared that the conduct of Odger and his allies was "inexplicable" and "calculated to injure the Reform League in the estimation of its patrons and also to do me personally immense injury". ${ }^{5}$ Cremer resorted to the familiar tactic of bringing counter charges against Odger. After recalling the shoemakers' failure to keep appointments and carry out instructions, he asked: "Is there any truth in the report that you received any money or promise of money, either directly or indirectly, from $\mathrm{Mr} \mathrm{M}$. T. Bass, $\mathrm{Mr} \mathrm{A}$. Bass or any other person speaking for them either directly or indirectly?... Did you receive any promise direct or indirect, from

1 Howell to Glyn, 12th. Dec. I 868.

2 E.C.R.L. Minutes, 2nd. Dec. 1868. (Moved by Odger, seconded by Dell.)-J. A. Samuda was a notorious foe of trades unionism. After he was returned in $\mathrm{I} 868$, he is alleged to have implored Gladstone to make no concessions to the unionists. (Henry Crompton, The Defeat of the Workmen, in: Bee-Hive, 2nd. Sept. 1868.) He beat Beales, but this may well have been due to the intervention, not of Glyn, but of Newton of the Engineers, who also stood for Tower Hamlets.

${ }^{3}$ Ibid.

${ }^{4}$ E.C.R.L. Minutes, 16th. Dec. 1868.

${ }^{5}$ Howell to Beales, toth. Dec. I 868 . 
Messrs M. T. or A. Bass, or from any other person speaking or acting for them, directly or indirectly, that either of the Basses or any other person would allow you $£$ ioo or any other sum per year towards your maintenance provided you would not come to Stafford and could get a seat elsewhere?".

The basis of this impressive questioning was a rumour that Odger, Connolly, and Cremer himself had received $£_{500}$ "as an inducement to withdraw Mr Odger from contesting Stafford". 2 There seems no doubt that M. T. Bass did offer to contribute $£_{1} \circ 0$ per year to a fund for the support of working men who were elected to Parliament. ${ }^{3}$ Mottershead was instructed to go to Stafford to investigate the whole matter, but the League was dead before his report was received. ${ }^{4}$

Apart from trying to show that their critics were as much implicated in private financial transactions with brewers and manufacturers as they were themselves, Howell and Cremer called upon Morley, Glyn and Beales to help exonerate them.

After many desperate appeals from Howell, Glyn was induced to address a letter to the League about his attitude to the Tower Hamlets election. It began with the haughty observation: "I can scarcely admit that I should be called upon to respond to the 'minute' of which you send me a copy". But he added, "You are at liberty to tell your friends that I am not aware that any action was taken by myself or others which can justify the supposition that Mr Samuda was supported by the Party at the expense of dividing the Liberal interest... I never attempted any interference and I am quite at a loss to understand the data upon which the allegation in the minute is based". ${ }^{5}$

Although this answer was hardly satisfactory from Odger's point of view it closed the discussion. The whole affair at Tower Hamlets was complicated by Newton's candidature. Cremer wanted an enquiry as to whether Allan, Applegarth, and "other leading trades unionists" had taken voters to the Poll to plump for Newton. ${ }^{6}$ Beales was the one "League" candidate who had received help from the Special Fund and he was satisfied with Glyn's explanation.?

\footnotetext{
${ }^{1}$ Minutes of ECRL, 2nd. Dec. 1868. The Basses were the famous brewers. M. T. Bass was the Member for Derby. He played an important part in the early history of trades unionism on the railways. (See G. W. Alcock, Fifty Years of Railway Trade Unionism, London, 1922.) Arthur Bass had been a candidate for Stafford (one of Glyn's "specials") but withdrew.

2 Ibid, gth. Dec. I 868.

${ }^{3}$ Ibid. (Remarks by Connolly, Mottershead and Odger himself.)

4 Ibid.

5 Copy of Glyn's letter in E.C.R.L. Minutes, I6th. Dec. 1868.

${ }^{6}$ Minutes E.C.R.L., sth. Dec. I 868.

7 Howell to Glyn, I 7 th. Dec. I 868. (Beales was seeking favours from the Ministry, Howell to Beales 12 th. Dec. I868.)
} 
Howell's great difficulty was the rejection of the report of the Finance Committee. Bradlaugh and others were determined to conduct a close enquiry into the expenditure of the Special Fund. Special meetings of the E.C. had to be held at which Odger, Cooper, Bradlaugh and others examined accounts and vouchers. ${ }^{1}$ Howell knew that the source of their discontent was the absence of any financial support for their own candidatures. In private, he spoke like Guizot, "enrichez vous". "If Mr Bradlaugh or Col. Dickson wants money to fight with, let them get it...".2 At the Executive he "misunderstood" all this probing and investigating. He behaved as if it was based on a suspicion that he had abused his official position for personal gain. This allowed him to whip himself up into a state of righteous indignation, for at the time of these debates neither Cremer nor himself had received special, preferential rates for their work. (They received their reward privately and only after the debate in the League had ended; nothing was allowed to appear in the accounts.)

Howell complained to Beales: "I had every item ready for the Executive last night. Why then, I ask, did not Mr Odger allow the balance sheet to be read and discussed in proper form and time instead of leading off into quite a different subject? Perhaps vile insinuations will serve their purpose better than the facts of the Balance Sheet". ${ }^{3}$

Beales eventually got the Balance Sheet adopted. ${ }^{4} \mathrm{Mr}$ Cooper said he never called the accounts in question, "what he deprecated was the policy involved in the matter; we had been used as Whig tools etc. The President replied that that was a very different matter and did not in any way interfere with the Report of the Finance Committee and the Balance Sheet. It was then put to the meeting and adopted". ${ }^{5}$

Howell explained to Samuel Morley: "I feel truly thankful that I have been able to give satisfaction to those who have chiefly sustained our great movement during the four years of its existence. As to the Special Fund, all have felt satisfied. Of course, there were a very few who have always more or less felt the same antipathy to the "Whigs" as William Cobbett, - but things are now greatly altered. All classes are drawn nearer to each other, and I hope it will not be long before the present jealousy will be considerably modified". ${ }^{6}$

The adoption of the balance sheet did not formally close the matter

${ }^{1}$ Minutes of Specially Summoned E.C.R.L., 8th. Jan. 1869.

${ }^{2}$ Howell to Beales, 2nd. Dec. I 868 (headed "Private").

${ }^{3}$ Howell to Beales, 1oth. Dec. I 868.

4 Minutes E.C.R.L., 23rd. Dec. I 868. Adoption moved by J. B. Langley, seconded by Wm. Osborne.

${ }^{5}$ Howell to S. Morley, 24th. Dec. 1868 .

${ }^{6}$ Howell to S. Morley, 2 Ist. Jan. 1869. 
because a rider was added "that the E.C. reserve its right to discuss the propriety and authority of a certain part of the expenditure", 1 but most of the critics had never been well placed to sustain their attack. They had tied their own hands in advance by their concessions and compromises. Those of them who stood as "League" or "Working Men's" candidates produced programmes which were little more advanced than those of such middle-class radicals as Mundella or Stansfeld. They all announced that, if elected, they would give general- or at most, "independent" - support to Mr. Gladstone. Bradlaugh, for example, always did his best to win the confidence of the Liberal chief. He sent him a copy of his election address and when he was planning a popular campaign against the obstruction of the House of Lords he told Gladstone that he did not want to do anything that might be detrimental to his plans. "The feeling of the people is so strong on the matter that controlled it may be useful, uncontrolled it will be dangerous". 2

Given the fact that men like Bradlaugh laid less stress on what distinguished them from other liberals than they did on what they had in common with Gladstone, they were not well placed to criticise their officers for putting first the overriding interests of the Party, as interpreted by Gladstone's Whips.

Some of those who were employed by Howell with money from the "Special Fund" may have known little about how the money was raised. This was true of Lloyd Jones who stipulated that he would only work for candidates who were sound on the Labour Question and who refused to take any payment even for expenses, for work done in London. ${ }^{3}$ But Odger and most of the others certainly knew a good deal of what was going on. Howell alleged that Odger was well aware that the Liberal Whips did not want any discussion about the "Special Fund" in the General Council and that they were only satisfied when Cremer and himself conducted all negotiations. Odger had received $£$ \& 8 for his work and had made no complaints until he was forced out of Chelsea. ${ }^{4}$ Having allowed Howell and Cremer to assume more and more power it was a bit late in the day to start complaining about the results.

All this mutual recrimination was finally ended early in 1869 . With only Osborne and West offering serious resistance, it was agreed to wind up the Reform League. ${ }^{5}$ A month or so before, members had

' Minutes E.C.R.L., 23rd. Dec. 1868.

2 Bradlaugh to Gladstone, 9th. June $\mathrm{I} 869$. (Date in pencil by another hand.)

${ }^{3}$ Lloyd Jones to Howell, 26th. Oct. I 868.

4 Howell to Beales, roth. Dec. I 868.

${ }^{5}$ Minutes E.C.R.L., I 2th. March I 869. 
been asked to console themselves for failures in the election by remembering that the League had "secured a hold on the constituencies never before attained by the Democratic Party"; ${ }^{1}$ now it was discovered that this impressive machine had outlived its usefulness. Cooper and the Left Wing thought that the time was ripe for a Republican ${ }^{2}$ agitation; Howell explained that the League had accomplished its main purpose; that he had every confidence in Mr Gladstone and that continual political agitation was bad for the country. ${ }^{3}$

Instead of reproaching each other about money matters everyone now agreed that everyone else's expenses ought to be met. It was agreed, in principle, that Cremer should receive a commission of $£_{90}$ on the last $£ 900$ raised in the Special Fund; ${ }^{4}$ that Howell's debt of $£_{1} 36$ at Aylesbury should be treated as a collective responsibility; ${ }^{5}$ finally, it was unanimously agreed that Odger should be voted $£_{75}$ for his election and other expenses. ${ }^{6}$

On I 3 th February 1869 George Howell wrote two letters which when placed side by side, provide a final, most revealing comment, on workmen, money, and the General Election.

The first of these letters was to a correspondent in Stoke. It will be remembered that Stoke had been the scene of Hartwell's candidature and a source of great anxiety to Glyn. ${ }^{7}$ In the end the old Chartist retired from the contest on the grounds that he had insufficient suplies. It was arranged that he should be paid $£_{2} 80$ to enable him to meet the expenses which he had already incurred, but he was swindled out of the money. ${ }^{8} \mathrm{He}$ tried to take action through the courts to restrain those who had defrauded him and in consequence, the episode became public knowledge.

Rumours were current in the Potteries that Howell was trying to discredit Hartwell and that he was actively involved in the intrigue against him. "I cannot but regret that my name has been mentioned in connection with your election", wrote Howell. "I do not think that I was treated fairly in the matter. However, I frankly state that I did not [?] know that Mr Hartwell was to be bought off or "induced to retire" as the expression was used. I sincerely respected my informant and I begged him not to dirty his fingers with the transaction. I own to an impression at the time that I was to be selected to do something in the matter. But so strongly was I opposed to it that I was told that it would be smashed up. I imagine that it was - so far as the first attempt was

1 Report of the Finance Committee of the Reform League, 9th. Dec. 1868.

2 Minutes E.C.R.L., 12th. March 1869.

3 Howell to Beales, Ioth. March 1869.

5 Ibid., 20th. Jan. I869.

7 See p. 79.

4 Minutes E.C.R.L., 13 th. Jan. 1869.

${ }^{6}$ I 2th. March I 869 .

${ }^{8}$ Standard, 20th. Nov. 1868. 
concerned. I felt that if working men's candidates were to be open to influences of this nature the cause of Labour was low indeed. Working men's candidates when once selected and in the field, must fight the battle out fairly, bonestly, and persistently to the end.

I would not retire from Aylesbury on any account. I felt that the honour of our class was in my hands, and I left the constituency with my name cherished not only by the $\mathrm{r}, 000$ who voted for me, but by all who had any pretension to the name of liberal". 1

The second letter was sent to an un-named correspondent. Its terms had been carefully discussed and it was signed by Cremer as well as by Howell. It read: "Private": "Dear Sir, In the various interviews we had with you during the late electoral campaign, you were pleased to acknowledge that the work which we had undertaken to perform had been done in a satisfactory manner and that we had rendered an essential service to the Liberal Party. We believe that you are satisfied that we preserved our connection with you as secret as possible considering the peculiar organisation and body of men with whom we had to deal. The difficulties of our task are only known to ourselves, especially, with regard to some circumstances which arose out of the Northampton, Hackney and Chelsea elections.

An endeavour was made to connect you with the novement, but completely failed inasmuch as we never would mention your name under any circumstances. Hence the public has never been any the wiser, although we got a little more abuse.

So far as we are concerned we were the least paid of all who went out, as our expenses were much heavier, whilst our pay was just the same in amount as any one of our co-workers, however humble his abilities or inadequate his work. Circumstances therefore compel us to ask you to consider our claims..."2

Cremer annoyed Glyn by the strong terms of his demands ${ }^{3}$ and irritated Stansfeld by wanting to claim money as a fee in the same way as a professional agent such as Acland. ${ }^{4}$ In the end Stansfeld advised that they should be paid $£ 200 .^{5}$

Howell had already received substantial help with his election expenses from Samuel Morley. "My gratitude", he said, "shall be shown by my future devotion to the same good work..."6

In March and April 1869, Howell proposed that the "same good

1 Howell to A. Smith of Stoke, I3th. Feb. I869.

2 Howell and Cremer to an unnamed correspondent, I 3 th. Feb. I 868 (headed "Private").

The correspondent was almost certainly Glyn. Howell's diary for 13 th. Feb. 1869 reads:

"Sent letter to Glyn about fee [sic] for work done..."

${ }^{3}$ Howell's diary, 3 rd. Feb. 1869 .

5 Ibid.

4 Ibid., 20th. Feb. 1869.

' Howell to Morley, 2 ist. Jan. 1869. 
work" could best be carried on through a private Registration and Election Agency. ${ }^{1} \mathrm{He}$ had already told Glyn that "In any work for the future I would see to it that I dealt only with those who found the money, and let all accounts, vouchers, etc. etc. be rendered to them". ${ }^{2}$

Morley, Glyn and Stansfeld supplied Howell with $£_{5} 00$ to establish this agency, ${ }^{3}$ but with the formation of the Labour Representation League at the end of the year Howell found himself in some danger of being isolated. He proposed that the balance of the $\mathfrak{L}_{500}$ should be made over to him personally so that he could be independent. "I own that I do not like trusting entirely to politics for one's bread. It lessens a man's moral influence and independence. I want to preserve both". He hastened to explain that he wanted to be independent, not of Morley or of Glyn, but of his own class. "I cannot always lend myself to all the foolish movements of working men". 4

Howell's proposal was accepted on the understanding that he would, in his words, continue to "as truely and fairly carry out the intention of the subscribers as though he went on as he was now doing". 5

At the end of 1867 Howell was delighted to have $£ 6$ in the bank; two years later his assets amounted to more than $£ 850 .{ }^{6}$ Both he and Cremer invested their money in old houses which they renovated. ${ }^{7}$ Howell tried to make his property the starting point for a bigger venture a philanthropic building society which was to pay $6 \%$.

In view of all this, it was quite an achievement for Howell to be able to assume a high moral tone about the misfortunes of Hartwell and to be able to declare that he would only be comforted when he knew that none of the "base money" reached him. ${ }^{8}$

However, Howell did not feel that he himself had been treated over generously and he complained at frequent intervals about the "stinginess" of the Gladstonians. Even in $\mathrm{x} 87 \mathrm{I}$, when he was Secretary to the Parliamentary Committee of the T.U.C., Howell was looking for favours from the Ministry and asking Beales to approach Glyn on his behalf. Glyn would do no more than "bear the matter in mind". "I sincerely thank you", wrote Howell to Beales, "for your kindness, and

'Howell to Stansfeld, 24th. April 1869.

${ }^{2}$ Howell to Glyn, 12th. Dec. 1868.

${ }^{3}$ Howell's rough notes on Balance sheet of Registration and Election Agency.

${ }^{4}$ Howell to Stansfeld, 2nd. Nov, 1869.

${ }^{5}$ Ibid.

"Howell's diary, I 868, "Personal Financial Review for the past year" \& the cash account at the end of the diary for $\mathrm{x} 869$.

${ }^{7}$ H. Evans, Sir R. Cremer: His Life and Work, London 1909, p. 48. \& Howell to S. Morley, 2oth. July $187 \mathrm{I}$.

${ }^{8}$ Howell to E. Hind, 3 rd. Dec. 1868. 
hope that Mr Glyn will bear the matter in mind for there are plenty of chances wherein he may, if he so pleases.

Mr Glyn should remember not merely good offices rendered, but the abstention from adverse criticism upon many points of the Government promise and performance. I, of course, could not do anything which would run the risk of a Liberal defeat, but upon some questions they have really invited it, and if we had been hasty in taking up the cudgels I think considerable dissatisfaction would have been the result.

I wonder if Mr Stansfeld ever remembers how some of us worked for him, now that he is reconstructing his office. Surely there would be a chance of some good appointment where my qualifications would be a fair test". 1

Beales had already received his judgeship. Howell and Cremer both had to wait until the eighteen eighties before becoming Lib-Lab Members of Parliament.

\section{VI}

As far as mere matters of fact are concerned it is no longer possible to dismiss Marx' judgement about "almost all" the recognised English Labour Leaders' being sold to Gladstone and Morley. There is no real release from this conclusion in pointing out that there were other "recognised leaders" apart from Howell, Cremer, Potter, Odger, Hales, Mottershead and the rest of them. In the first place, Marx qualified his charge. In the second, such men as Applegarth had, by the time Marx spoke, started to engage privately in work for "Glyn and the Government". ${ }^{2}$

It is, however, possible to argue that Howell and Cremer ought not to be judged by the political moralities of either chartism or of socialism. It is not self-evident that Howell was betraying his own social and political values when he made his agreement with Glyn. It might be suggested, and very plausibly, that Cremer and he were empiricists; practical men who believed that any programme that looked beyond limited improvements was delusory and nonsensical. They believed, with equal sincerity, in Mr Gladstone; in "new model" unionism; and in the adage about the half loaf. They could see little incompatibility between the interests of their industrial organisations and their political loyalties.

Once this is granted, their secrecy, their shiftiness, the readiness

1 Howell to Beales, 23rd. August 1871 .

${ }^{2}$ A. J. Mundella to R. Leader, 13 th. Oct. I 87 I. Sheffield University Library. (A postscript to the letter headed "Private" runs: "Applegarth works for Glyn whenever needed, and is always ready to help the Government".) 
with which they sacrificed their friends take on the aspect of unpleasant, but indispensable, expedients.

It must not be forgotten that most contemporary labour leaders shared Howell and Cremer's attachment to liberalism. For example, John C. Proudfoot, a leading trades unionist in Scotland, was even more attached to the principles expressed in the essay "On Liberty" than they were themselves. Proudfoot told Lord Elcho: "I agree with your Lordship in believing that this class (the working class) is in great need of being taught that the true liberty is individual or personal liberty and that communal or mob liberty or happiness or progress at which most of their would-be leaders aim is... tyranny over body and mind".1 Proudfoot favoured "labour representation, provided that there was no suggestion of independent class policies and that "the right men" were chosen. "I do believe in the propriety of a few working men getting into Parliament as I deem it a sine qua non that all classes should be represented, but Potter and Co are not the men". (He was discussing Hartwell's candidature at Stoke.) "I believe them as destitute of the necessary intellect as of honesty and that is saying something considerable I deem. Potter himself is about as honest as any of them, though certainly not the ablest, although his vanity would lift him over all heads". 2

An apologist for Howell and Cremer could argue that the workmen and reformers who came forward as candidates in Hackney or Nottingham, Halifax or Northampton, were not advancing programmes which were conspicuously different from those of many middle-class Gladstonians. The challenge which they made to local Whig interests or to middle-class wire pullers was therefore dangerous where it stood any chance of letting in the Tory and merely trivial where it did not. If mere labour representation was all that was wanted, it was more likely to be secured by services rendered to the Whips than by making a nuisance of yourself in the constituencies.

If Howell and Cremer were rewarded with a "small independence" for themselves, there was nothing particularly reprehensible about it. Applegarth and Coulson had occupied the official positions which they might otherwise have expected to have secured for themselves and they had made a notable contribution to supplying $\mathrm{Mr}$ Gladstone with the majority upon which his first, great administration depended.

It could be maintained that when the reforms of that first administration are remembered; the disestablishment of the Irish Church; the

' J. C. Proudfoot to Lord Elcho, n.d. (Gosford House archives. Courtesy of Earl of Wemyss and March).

${ }^{2}$ Ibid., 8th. August I 868. 
improvement in the Irish land laws; the beginnings of army reform; the Education Act of $187^{\circ}$; and the introduction of the ballot; faith in Gladstone does not appear to have been misplaced.

Even if Howell knew (as he did) that the middle-class radicals of Bradford and elsewhere were doubtful friends to trades unionism, what else could he do? Even if he saw (as he did) support for "advanced radical reformers" degenerating into general support for all candidates approved by the Whips, what could he do? Given the state of political opinion in England and the structure of politics at that time, it may be questioned whether there was any alternative course open to the leaders of the League except collaboration with Gladstone.

The plausibility of this defence largely depends on showing that Howell and Cremer had no choice, or that if they had a choice, they were not aware of it; or that if they were aware of it they conscientiously rejected it.

There was an alternative policy, although it must be recognised that it was neither well articulated nor strongly supported. Engels was being wildly unrealistic when he said that the Reform Act opened the door of the House of Commons to sixty labour M.P.s - this showed no appreciation of the importance of the ballot or the tremendous cost of elections. But it might have opened the door to some, had workmen been more conscious of their strength and encouraged by their leaders to use it. Glyn was obviously astonished by the modest ambitions of the Reform League leadership and amazed by their unconditional support of Gladstone. Had they demanded concessions on matters of policy and a share of representation he might well have tried to help them to get it.

The alternative to Howell's policy of complete identification with middle-class radicalism was most clearly set forth in Professor Beesly's programme. ${ }^{1}$ It will be recalled that Beesly attached no importance to mere labour representation as such. A few workmen in the Parliamentary Liberal Party would simply have come up "night after night to the crack of Mr. Glyn's whip; compromising their convictions, soiling the purity of their own consciences and ruining their chances of future usefulness"'. A few working-class candidates would be useful provided their appearance was part of a larger strategy of mass pressure behind a distinctive programme.

There are a number of reasons why it would be quite wrong to dismiss Beesly's ideas as a professorial flight of fancy. The first, and most impressive of them, is that the essentials of his strategy were taken up

${ }^{1}$ See first part of this article, Vol. V (1960), Part 3, p. 430.

${ }^{2}$ E. S. Beesly, The Elections, in: Bee-Hive, 12 th. Dec. 1868. 
and applied at a number of by-elections in the early seventies and at the General Election of 1874 . This made an important contribution to securing the satisfactory legal settlement for the unions in $1875^{1}$. Howell's policy, on the other hand, broke down in 1872 when his industrial and political loyalties came into open conflict with each other. As secretary of the Parliamentary Committee of the T.U.C. he could not carry out Congress' instructions to bring mass pressure to bear on the Liberal Government and to settle for nothing but the total repeal of the Criminal Law Amendment Act. ${ }^{2}$ His earlier commitment to Glyn and Gladstone made it impossible for him to do this. Congress would have better understood the strange reticence of its secretary had it known that he had made an impressive contribution to the Government's majority and that he had been set up in business by the Whips on the understanding that he would continue to work for the Party.

But even in 1868 , Beesly was not alone in pointing to an alternative. There were workmen who were feeling their way towards independent political action along the lines which he suggested. For example, there was the Scottish workers' programme, developed by the men of Edinburgh and Leith. It consisted of is test questions for candidates on questions of social legislation of interest to the working class. The first question was: "Are you in favour of extending the full protection of the law to the funds of trades unions...?" Other questions covered: widening the penalties for employers' negligence; the extension of the factory acts; further amendment of the Master and Servant Acts; more legislation and inspection for mines and sea-going vessels; state ownership of railways; a national compulsory, unsectarian, system of education; and compulsory provision of full house accommodation for workmen evicted from their homes as a consequence of civic improvements or other causes. ${ }^{3}$

The acceptance of the Gladstonian principles of public finance and total rejection of state intervention in economic and social life was by no means as widespread in the eighteen sixties as has sometimes been supposed. The London working-class leaders knew the Fortnightly Review in which the Editor talked of jargon about "retrenchment" being essentially hollow and hypocritical; a favourite phrase of the "unidea'd rich". And went on to speak of the ragged flag of economy being paraded as if it were a holy lance. ${ }^{4}$

\footnotetext{
${ }^{1}$ R. J. Harrison, The English Positivists and Labour Movements, D. Phil. Thesis, Oxford I955.

2 See the controversy between Beesly and Harrison on the one hand and Howell on the other in the Bee-Hive between I 3 th. Jan. and I 4 th. June 1872.

3 The Kilmarnock Advertiser, 3 Ist. Oct. 1868.

4 J. Morley, Old Parties and New Policy, in: Fortnightly Review, September 1868.
} 
All the way from Lloyd Jones and Hartwell at one extreme to Applegarth and Odger at the other, workmen retained the sense of their own identity and distinct interests. This awareness might be dulled but it could not be wholly eradicated. It was there behind the halting and uncertain gestures of some of the working-class candidates in 1868 . It helps to explain the rise of British republicanism in the seventies, and it was at the source of the continual tension that characterised the inner history of both the Reform and Labour Laws agitations. The policies of empiricism and compromise were always under a challenge; usually muted and feeble; occasionally stern and formidable. Howell knew about this. It was at the root of most of his problems in managing the League. It was always threatening to assume the shape of an alternative policy. As he told Stansfeld, "Some of us have to stand in the character of obstructives because we will not consent to the revival of the old chartist practice, that of opposing all parties except those pledged to labour questions". 1

One can understand neither the movements nor the men of the Mid-Victorian Labour Movement if the ambivalent attitudes referred to at the beginning of this article are lost sight of. Liberalism at the front of the mind and old working-class sentiments and traditions at the back of it, produced the characteristic vacillations and inconsistencies. Applegarth secretly working for Glyn and the Government, and at the same time valuing his membership of the International; Odger in 1868 , at once party to an agreement with the Liberal Whips and yet in rebellion against it.

The point is illustrated by the superb irony of Odger's peroration at Fawcett's eve of poll meeting in Brighton. The shoemaker took as his theme that most cherished and ambiguous of Victorian virtues, self-help. "Rely upon yourselves! Self-reliance, - that rising, animating, soul-stirring, heart-inspiring quality which whispers to a man; - no matter whether he be a shoemaker in his kitchen or a tailor in his garret, an engineer at his lathe, a bricklayer or a mason on his scaffolding, - whoever he may be, be strong in the spirit of self-reliance, the faithful monitor which whispers into the deepest recesses of his soul, and says in gladdening tones - 'Look up! There's a brighter and happier future before you"'.

The general working class sympathy with Liberalism and Radicalism would not have been enough in itself to have prevented some advance along the lines of Beesly's programme. The intellectual dependence of the Labour Leaders upon the Gladstonians was never so great as to

${ }^{1}$ Howell to J. Stansfeld, 8th. Nov. 1869.

2 Brighton Gazette, 18 th. Nov, I 868. 
make their financial dependence upon them unimportant or merely incidental. It was this "iron power", as Howell himself termed it, ${ }^{1}$ which enabled Glyn to re-enforce and consolidate the exceedingly skilful social and educational efforts of Stansfeld and Mundella. If the Amalgamated Engineers could have been induced to give $£_{3,000}$ to a working class electoral fund, as they were induced to give the same sum to the London builders, the history of the I 868 Election might have been very different.

The secret agreement of 1903 may have had beneficial consequences for both parties; it is an arguable matter. The agreement of i 868 was essentially what Howell called it - "a contract". From this contract, the Liberal Party derived immense benefits at very little cost; the labour movement derived no obvious benefit at all. As a result of the negotiations with the Whips, support for "Advanced Radical Reformers" became synonymous with support for Whigs like Akroyd and Lord Henley. And if there was any advantage in returning Mundella for Sheffield it was balanced by helping to defeat Butler-Johnstone at Canterbury. By their unconditional support for Gladstone, Howell and Cremer helped to create a Government with so vast a majority that it became insensitive to the claims of Labour.

Howell and Cremer derived undeniable advantages for themselves by their deal with the Whips. Yet it is apparent from Glyn's remarks to Gladstone that they began by putting too low a price upon their services and that had they played their cards properly they might have been rewarded with more promising constituencies than Warwick and Aylesbury. Perhaps they underpriced themselves because they did not appreciate that Glyn was full of doubts and anxieties about the outcome of the election. At the beginning of 1868 they could hardly have guessed that the Liberal Whips would come to attach so much importance to the machinery of the Reform League. It seems probable that Howell always believed that the Liberals would win the Election. He may well have interpreted the close-fisted behaviour of the Northern manufacturers during the winter of $1867-68$ as a sign that they shared his confidence. If victory was certain, then the Reform League could only be of marginal importance.

It was only as the election campaign developed that Howell gradually recognised how much Glyn needed the League. If he lamented his missed opportunities and came to complain about the stinginess of Glyn and Stansfeld, he could console himself with the thought that he had made enough to make him, in his own words, "independent". However, he lived under the constant strain of the invidious position

${ }^{1}$ Howell to J. D. Nieas, 22nd. August 1868. 
in which he had placed himself. His relations with his associates became charged with bitterness and mutual contempt. He came to talk of his old friend Dickson as "simply a man about Town, he never was a politician". Mottershead, he accused of writing "scurrilous rhymes, without power or reason, or common sense, to lampoon or libel all with whom he comes in contact. Shunned by all...". "As to the cantankerous little dog Cremer, he is doing all the mischief in his power as usual". Odger "has done us much harm during the last two years by his foolhardiness and by his ill-governed temper. But it pays him somehow for he is well up for cash..."1 "Whoever found Cremer working for long with any party except pay kept him quiet for a while?"2 Howell's correspondence abounds with this sort of thing. He acquired, in turn, an unenviable reputation as a man who had "never worked for or been identified with any reform movement where the money was scarce and hard work the only reward". ${ }^{3}$

The historical significance of the 1868 agreement is that it marked the real beginning of the Lib-Lab era in working-class politics; an era which was to last well beyond the formation of the Labour Representation Committee in 1900. Surrounding that meeting in the Memorial Hall there was an unnoticed irony - the money for the building had been largely supplied by Mr. Samuel Morley. ${ }^{4}$

1 Howell to C. Bartlett, 27 th. June 1871 .

2 Ibid., 9th. Jan. 1871.

${ }^{3}$ F. W. Soutter, Recollections of a Labour Pioneer, 1923, p. I 20.

4 The Englishman, roth. June 1876 . ("This is MORLEY's Shop, he having been the largest contributor to the erection of the building, and it is the home of very [every?] milk-andwater kind of gospel...") 